Available online at GSC Online Press Directory

GSC Biological and Pharmaceutical Sciences

e-ISSN: 2581-3250, CODEN (USA): GBPSC2

Journal homepage: https://www.gsconlinepress.com/journals/gscbps

(RESEARCH ARTICLE)

\title{
An appraisal of heavy metals in water column and bottom substrate of Aba river,
} Abia state, Nigeria

\author{
Alagoa Koru Joe \\ Department of Biological Sciences, Niger Delta University, Amassoma, Bayelsa State Nigeria.
}

Publication history: Received on 09 February 2019; revised on 09 March 2019; accepted on 12 March 2019

Article DOI: https://doi.org/10.30574/gscbps.2019.6.3.0021

\begin{abstract}
The level of heavy metals in water and sediment of Aba River was measured in order to determine the pollution status of the river and the effect of riparian influences. Five sampling stations were identified located at coordinates, $05^{\circ} 07^{\prime}$

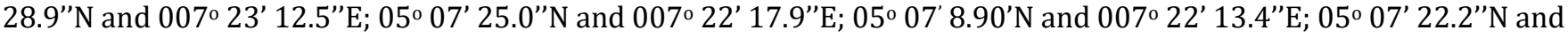
$007^{\circ} 21^{\prime} 844^{\prime \prime} \mathrm{E} ; 05^{\circ} 07^{\prime} 44.9^{\prime \prime} \mathrm{N}$ and $007^{\circ} 22^{\prime} 836^{\prime \prime} \mathrm{E}$ representing stations 1 to stations 5 respectively. Subsurface water and sediment samples were collected for laboratory analysis. A total of 30 samples were collected (15 for water, 15 for sediment). Samples were analyzed for copper (Cu), cadmium (Cd), chromium (Cr), lead (Pb) and nickel (Ni) using standard techniques. Data were statistically analyzed using the Microsoft Excel ${ }^{\circledR}$ tool pack. Results indicate higher concentrations of heavy metals in sediments than in water. Heavy metals in sediments exceeded the suggested international limits. Apart from Nickel, all the other heavy metals showed low $(<0.001)$ concentrations in water column. There was significant difference between stations in metal parameters in sediments $(\mathrm{P}=0.05)$. Ni values were positively correlated in water and sediment $\left(r^{2}=0.25\right)$. Based on observation from this study, it can be concluded that Aba River is polluted due to land activities and therefore a need to enact regulatory ordinances to protect its ecology.
\end{abstract}

Keywords: Heavy metals; Water column; Bottom substrate; Aba river

\section{Introduction}

Aba is the business capital or commercial center of Abia State in Nigeria. It is located on the Aba River in the Ngwu hinterlands at the intersection of roads leading to Port Harcourt, Owerri, Ikot Ekpene and Ikot Abasi. It is touted as the China of Africa because of the myriads of sprawling industries and commercial businesses. It has become a persona of genius, innovation and creativity. Expectedly, massive waste generation is an inevitable outcome of industrialization and massive production. Sadly, most of the waste generated are either littered indiscriminately in street corners and water drains or are washed into water bodies where they cause unfathomable damage to aquatic biota and the environment. These wastes are constituted by different chemical components including heavy metals that are harmful to man and result in the declining quality of the water bodies. Despite this threat to water quality and the entire aquatic ecosystem, most threatened waters have gone without scrutiny. Aba River despite its strategic positioning and significance is relatively understudied and scarcely cited in scientific literature [1].

As Aba River provides outstanding catchments area that host lots of industries and other businesses, there is an urgent need to study the concentration levels and spatial distribution of selected heavy metals in the water column and sediment of Aba River so as to determine its pollution status. This work was done to establish the existing levels of heavy metals in the Aba River in order to ascertain the degree of its threat to the environment. This will provide valuable information to government and scholars as regards the protection of its fisheries resources and the promulgation of land use laws.

\footnotetext{
${ }^{*}$ Corresponding author

E-mail address: mrkjalagoa@yahoo.com
}

Copyright (C) 2019 Author(s) retain the copyright of this article. This article is published under the terms of the Creative Commons Attribution Liscense 4.0. 


\section{Material and methods}

\subsection{Description of study site}

Aba River lies between latitude $5^{0} 30^{\prime}-5^{0}$ 07' and longitude $7^{0}$ 17' - 70 24' in Abia State of Nigeria. The river drains the forest of the Northern Ngwa hinterlands of Abia state and empties into Imo River through Ndoki. Study stations were identified and established after a survey of land use pattern along the river catchments.

\subsubsection{Station 1}

This Station is located at $05^{\circ} 07^{\prime} 28.9^{\prime \prime} \mathrm{N}$ and $007^{\circ} 23^{\prime} 12.5^{\prime \prime} \mathrm{E}$. It has an elevation of $67 \mathrm{ft}$. It is downstream of the river and situated in a sparsely populated area. It mainly serves as a point for ferrying across the river in small wooden canoes. It is a source of water for all sorts of domestic uses. Children and adults were seen bathing, washing cloths and bitter leaf for cooking. The vegetation of the area consists mainly of lush green Elephant grasses.

\subsubsection{Station 2}

It is located upstream of station1 just before the drainage system of the PZ industries limited. It was strategically chosen to capture the drainage points of the industries of the river catchments. Other notable industries around the area include Vitafoam Nigeria Plc, IEA Ltd and Uniliver Nigeria Plc. The vegetation of the station consists mainly of luxuriant climber plants. It has an elevation of $26 \mathrm{ft}$ and lies between; $05^{\circ} 07^{\prime} 25.0^{\prime \prime} \mathrm{N}$ and $007^{\circ} 22^{\prime} 17.9^{\prime \prime} \mathrm{E}$.

\subsubsection{Station 3}

This station has an elevation of $35 \mathrm{ft}$ and lies between latitude $05^{\circ} 07^{\prime} 8.90^{\prime} \mathrm{N}$ and $007^{\circ} 22^{\prime} 13.4^{\prime \prime} \mathrm{E}$.

The station is located at the waterside bus stop by the Uzor Orji Kalu Bridge where there is a car wash depot. Another notable feature of this station is the location of a piggery. People were also seen taking their baths. The vegetation of this station is very scanty.

\subsubsection{Station 4}

This station is located at an elevation of $11 \mathrm{ft}$ and lies between latitude $05^{\circ} 07^{\prime} 22.2^{\prime \prime} \mathrm{N}$ and $007^{\circ} 21^{\prime} 8.44^{\prime \prime} \mathrm{E}$ upstream of station 3 . The station is characterized by the presence of a big abattoir.

It is also a bathing place for locales. The station is nearly without vegetation at the fringe bordering the abattoir and contains less vegetation compared to station 3.

\subsubsection{Station 5}

The station lies between latitude $05^{\circ} 07^{\prime} 44.9^{\prime \prime} \mathrm{N}$ and $007^{\circ} 22^{\prime} 8.36^{\prime \prime} \mathrm{E}$ at an elevation of $70 \mathrm{ft}$. The station is located at the point of heavy human settlements and a car wash. Water hyacinth (Eichhornia crassipes) can be seen all over.

\subsection{Sample collection}

\subsubsection{Water sample}

At each station, triplicate samples of sub-surface water samples were collected for heavy metals using a $250 \mathrm{ml}$ plastic bottle All samples were stored in an ice chest $\left(<40^{\circ} \mathrm{C}\right)$ before transferring to the laboratory.

\subsubsection{Sediment samples}

Sediment samples were collected using a hand trowel to scoop sediments into polyethylene bags for heavy metal analysis. In each station, triplicate samples were collected and stored in an ice chest before transferring to the laboratory.

\subsection{Laboratory analysis}

\subsubsection{Water quality of samples}

In the laboratory, the water samples were filtered using a $45 \mathrm{~mm}$ Whatman filter paper. The filtrates were then digested with a mixture of $10 \mathrm{ml}$ of concentrated nitric acid and $2 \mathrm{ml}$ of concentrated Perchloric acid respectively. The content was then digested slowly by heating it in a water bath. The samples were the allowed to cool and then put in a conical 
flask. Analysis for five (5) heavy metals; copper, cadmium, lead, nickel and chromium conducted using the flame atomic absorption spectrophotometry with Buck scientific model 200A Spectrophotometer equipped with a high sensitivity nebulizer using their different wave lengths .

\subsubsection{Sediment sample analysis}

In the laboratory, five (5) grams of the air-dried samples were weighed out accurately using a sensitive micro-scale for each station. The samples were put in a $250 \mathrm{ml}$ beaker and the following chemicals added to each weighed sample. (a) $100 \mathrm{ml}$ of distilled water. (b) $1 \mathrm{ml}$ of concentrated Nitric acid ( $\left.\mathrm{HNO}_{3}\right)$. (C) $10 \mathrm{ml}$ of concentrated Hydrochloric acid.

The beaker containing weighed samples plus acid mixture were then covered with watch glasses and were placed on a hot plate for digestion to be completed. The solutions were not allowed to boil nor bump to avoid splattering. The digestion was continued until the volume was concentrated to about $15 \mathrm{ml}$. It was the allowed to cool to room temperature. The digested samples after cooling were filtered quantitatively into a $50 \mathrm{ml}$ volumetric flasks and the volume made up to mark with distilled water. The solutions were then introduced to the AAS - GBC Avanta P.M model equipment for quantitative measurement of the metals.

\subsection{Data analysis}

Means and standard errors were calculated for all heavy metals values. Regression analysis was employed using the Microsoft Excel@ tool pack in order to determine the correlation between heavy metals in bottom sediments and water. Analysis of variance was employed at the $95 \%$ confidence level to determine the degree of significance of heavy metals in study stations.

\section{Results and discussion}

The result of the study is represented in Tables 1 and 2. Table 1 show that except for the metal Nickel, that exhibited appreciable quantities in all sample stations, all other heavy metals showed negligible or non-detectable values in water samples. Table 2 show that chromium exhibited negligible values in sediments. All the other metals show appreciable values in sediment.

Table 1 Concentration of heavy metals in water column in Aba river

\begin{tabular}{|c|c|c|c|c|c|}
\hline \multirow{2}{*}{$\begin{array}{l}\text { Parameters } \\
\text { (mg/kg) }\end{array}$} & \multicolumn{5}{|c|}{ Stations } \\
\hline & 1 & 2 & 3 & 4 & 5 \\
\hline Copper & $<0.001^{\mathrm{a}}$ & $<0.001^{a}$ & $<0.001^{a}$ & $<0.001^{a}$ & $<0.001^{a}$ \\
\hline Cadmium & $<0.001^{\mathrm{a}}$ & $<0.001^{\mathrm{a}}$ & $<0.001^{\mathrm{a}}$ & $<0.001$ & $<0.001^{\mathrm{a}}$ \\
\hline Chromium & $<0.001^{\mathrm{a}}$ & $<0.001^{\mathrm{a}}$ & $<0.001^{a}$ & $<0.001^{\mathrm{a}}$ & $<0.001^{\mathrm{a}}$ \\
\hline Lead & $<0.001$ & $<0.001$ & $<0.001^{\mathrm{a}}$ & $<0.001^{\mathrm{a}}$ & $<0.001^{\text {a }}$ \\
\hline Nickel & $0.048 \pm 0.02^{\mathrm{a}}$ & $0.072 \pm 0.01^{b}$ & $0.081 \pm 0.01^{b}$ & $0.121 \pm 0.03^{c}$ & $0.099 \pm 0.02^{c}$ \\
\hline
\end{tabular}

Table 2 Concentration of heavy metals in bottom sediment of Aba river

\begin{tabular}{|c|c|c|c|c|c|}
\hline \multirow[t]{2}{*}{ Parameters (mg/kg) } & \multicolumn{5}{|c|}{ Stations } \\
\hline & 1 & 2 & 3 & 4 & 5 \\
\hline Copper & $2.67 \pm 0.02^{a}$ & $1.02 \pm 0.01^{b}$ & $6.87 \pm 1.2^{c}$ & $1.85 \pm 0.1^{d}$ & $1.91 \pm 0.5^{\mathrm{d}}$ \\
\hline Cadmium & $<0.006 \pm 0 .{ }^{a}$ & $0.06 \pm 0.001^{a}$ & $0.36 \pm 0.1^{b}$ & $<0.001 \pm 0.0 \mathrm{a}$ & $0.10 \pm 0.02^{c}$ \\
\hline Chromium & $<0.0011^{a}$ & $<0.001^{a}$ & $<0.001$ & $<0.001^{a}$ & $<0.001^{a}$ \\
\hline Lead & $0.33 \pm 0.1^{\mathrm{a}}$ & $0.15 \pm 0.02^{b}$ & $0.44 \pm 0.2^{\mathrm{a}}$ & $0.05 \pm 0.03^{c}$ & $0.18 \pm 0.3^{b}$ \\
\hline Nickel & $1.73 \pm 0.021^{\mathrm{a}}$ & $1.54 \pm 0.02^{\mathrm{a}}$ & $2.12 \pm 0.1^{b}$ & $1.66 \pm 0.43^{\mathrm{a}}$ & $2.51 \pm 0.3^{b}$ \\
\hline
\end{tabular}


Table 3 Maximum Contaminant levels for heavy metal concentration and water supporting aquatic life and criteria for open water disposal of polluted sediments

\begin{tabular}{lllll}
\hline Source & Cadmium & Chromium & Copper & Lead \\
\hline Drinking Water in $\mu \mathrm{g} / \mathrm{L}$ & - & 100 & 1,000 & 15 \\
Water supporting aquatic life $\mu \mathrm{g} / \mathrm{L}$ & 12 & 100 & 20 & 100 \\
Natural sediments, non-polluted $\mu \mathrm{g} / \mathrm{g}$ & - & $<25$ & $<25$ & $<40$ \\
Natural sediments moderately polluted $\mu \mathrm{g} / \mathrm{g}$ & - & $25-70$ & $25-50$ & $40-60$ \\
Natural sediments heavily polluted $\mu \mathrm{g} / \mathrm{g}$ & $>16$ & $>75$ & $>50$ & $>60$ \\
\hline
\end{tabular}

Source: U.S Environmental Protection Agency (USEPA), 1992

Table 4 Interim standard for aquatic life water quality

\begin{tabular}{|c|c|}
\hline Parameter & Value/Standard Unit \\
\hline $\mathrm{pH}$ & $6.0-9.0$ \\
\hline Temperature & $20-33^{\circ} \mathrm{C}$ \\
\hline Total Suspended Solids & - \\
\hline DO & 6-8 mg/L \\
\hline BOD & $4.0 \mathrm{mg} / \mathrm{L}$ \\
\hline Foaming Agents & NS \\
\hline Oil and Grease & NS \\
\hline Phosphates & NS \\
\hline Aluminium( $\mu \mathrm{g} / \mathrm{l})$ & $0.005-0.1$ \\
\hline Antimony $\mu \mathrm{g} / \mathrm{l})$ & 0.6 \\
\hline Arsenic $(\mu \mathrm{g} / \mathrm{l})$ & 0.5 \\
\hline Beryllium & NS \\
\hline Cadmium ( $\mu \mathrm{g} / \mathrm{l})$ & 2.0 \\
\hline Copper $(\mu \mathrm{g} / \mathrm{l})$ & $1 \mathrm{mg} / \mathrm{l}$ \\
\hline Cyanide (free CN) $(\mu \mathrm{g} / \mathrm{l})$ & 5.0 \\
\hline Iron $(\mu \mathrm{g} / \mathrm{l})$ & 1.0 \\
\hline Lead $(\mu \mathrm{g} / \mathrm{l})$ & 1.7 \\
\hline Mercury $(\mu \mathrm{g} / \mathrm{l})$ & 1.0 \\
\hline Nickel $(\mu \mathrm{g} / \mathrm{l})$ & $25-150 \mathrm{~b}$ \\
\hline Ammonia (Total) & $2.2-1.37(\mu \mathrm{g} / \mathrm{l})$ \\
\hline Nitrite & 0.06 \\
\hline Nitrate (as N) & $20.0 \mathrm{mg} / \mathrm{l}$ \\
\hline Nitroamines & 1.0 \\
\hline Pattassium & 1,0 \\
\hline Selenium ( $\mu \mathrm{g} / \mathrm{l})$ & 1.0 \\
\hline Silver $(\mu \mathrm{g} / \mathrm{l})$ & 1.0 \\
\hline Chloride & $250 \mathrm{mg} / \mathrm{l}$ \\
\hline Chromium ( $\mu \mathrm{g} / \mathrm{l})$ & $0.2-2.0 \mathrm{~d}$ \\
\hline
\end{tabular}

The concentration of the heavy metals $\mathrm{Cu}, \mathrm{Cd}, \mathrm{Cr}$ and $\mathrm{Pb}$ were all present at uniformly low (negligible) levels $(<0.001)$ in the water column of Aba River in all sampling stations. However, Ni showed appreciable concentration levels in all stations (Tables 1). The concentration of $\mathrm{Ni}$ and other heavy metals in water were lower than the maximum allowable limits stipulated by USEPA, [2] and FEPA, [3] (Tables 3 \& 4). A reason for the low levels of these heavy metals in the water column may be as a result of the fact that heavy metals have a tendency to be either absorbed in living tissues or bottom sediments than to be carried around in water. Okafor and Opuene [4] affirmed that sediments have been 
employed to monitor the pollution of aquatic environments for the reason that trace metals which exist in low concentration in water column, have a propensity to associate and attain considerable high concentrations in sediments. Lead and Zinc for example from mine wastes tended to be adsorbed onto natural silt and clay sediments or organic matter, rather than staying dissolved in the water of Mississippi River [5]. Another reason for the appreciable concentration of $\mathrm{Ni}$ in the water column may be as a result of the fact that $\mathrm{Ni}$ is widely available to aquatic ecosystem through a variety of anthropogenic sources such as household waste waters and other inputs. In this study stations 4 and 5 which are located adjacent to an abattoir and car wash respectively produced the highest amounts of Ni respectively.

The concentrations of the heavy metals in sediments are shown in Tables 2. Except Cr, the presence of heavy metals in sediment is due to their easy affinity for bottom sediments and plant tissues. Bottom sediment pollution is considered by many regulatory agencies to be one of the largest risks to the aquatic environment, since many aquatic organisms spend the major part of their life cycle living on or in sediments [6]. The low concentration of Cr in the sediments can be explained by the fact that $\mathrm{Cr}$ is considered as a metal with low biogeochemical mobility which reduces its availability and toxicity potential [7].

There was high concentration of $\mathrm{Pb}, \mathrm{Cu}$, and $\mathrm{Cd}$, in sediments of the study sites. High Pb levels in Aba River could be traced to urban and Industrial waste and high petrol-lead used by vehicles in Nigeria [8, 9]. This is in agreement with the observation of this study as a lot of fuel and fuel by products are washed off from cars in the car wash. Pb in the environment is of concern because it is a cumulative poison in humans and is toxic to many aquatic organisms at low concentration [10]. Black [11] noted that poly aromatic hydrocarbons (PAHs) concentration in the Great Barrier Reef Australia were always $<0.8 \mu \mathrm{g} / \mathrm{kg}$ dry weight in some sites and exceeded 13,400 $\mu \mathrm{g} / \mathrm{g}$ in other sites with heavy human activity. Sediments and sediment extracts from the Buffalo River New York contained elevated levels of carcinogenic PAHs $(1,000-16,000 \mu \mathrm{g} / \mathrm{kg})$ [12]. Metal availability and interactions in soils is determined by the nature of the soil types [13]. Also, certain water chemistry parameters such as $\mathrm{pH}$ and oxygen levels control the rate of adsorption and desorption of heavy metals to and from the sediments [13]. Cadmium for instance is a Sulphur seeking metal that tends to precipitate in anoxic sediments [7]. In general, the amount of heavy metals in sediments exceeded the stipulated limit for safe and portable water (Tables $3 \& 4$ ). Ni concentration in water was positively correlated with that in sediment $\left(r^{2}=0.25\right)$. There were no correlation between other metals studied in water and sediment. Aba River considering its heavy metal characteristics in sediments indicates a possible contamination from land based activities. There is therefore an acute need to regulate the further contamination of the River and protect its fisheries.

Table 5 Correlation co-efficient of Nickel in water and sediment

\begin{tabular}{lll}
\hline Medium & Water & Sediment \\
\hline Water & 1 & \\
Sediment & 0.25 & $\mathbf{1}$ \\
\hline
\end{tabular}

\section{Conclusion}

Aba is copiously dotted with manufacturing and business concerns. Large amounts of waste are released into the environment daily without treatment. Therefore the level of heavy metals in water and sediment was investigated in Aba River. The study revealed that higher concentrations of heavy metals were found in sediments than water samples and exceeded the suggested international limits. Nickel showed the most appreciable concentration than copper (Cu), cadmium (Cd), chromium $(\mathrm{Cr})$ and lead $(\mathrm{Pb})$ in water, while $\mathrm{Cu}$ and $\mathrm{Ni}$ were the most appreciable in sediments. It can be concluded that Aba River is polluted due to land activities and therefore there is a need to enact regulatory ordinances to protect its ecology and prevent further contamination of the river.

\section{Compliance with ethical standards}

\section{Acknowledgments}

I hereby express my sincere thanks to Mr. Spiff of the Department of Chemistry, Niger Delta University who painstakingly undertook the analyses of all samples from the field. To my Wife and children who provided encouragement and moral support during the research period. 


\section{References}

[1] Anunobi CK. (2008) The physico-chemical and heavy metal characteristics of Aba River in Aba, Abia State. M.phil Thesis, Rivers State University of Science and Technology, Port Harcourt, 100.

[2] United States Environmental Protection Agency (1986) Manual for waste testing volumes. IB and IC. SW-846, Washington DC.

[3] FEPA (1991) Guidelines and standards for environmental pollution in Nigeria.

[4] Okafor EC and Opuene K. (2007). Preliminary assessment of trace metals and polycyclic aromatic hydrocarbons in the sediments. International Journal of Environmental Science and Technology, 4(2), 233-240.

[5] Jennett JC, Wilson BG, Boller E and Gale N. (1973) Transport Mechanisms of lead industry wastes. In proceedings of industrial waste conference $28^{\text {th }}$ Purdue, university: Boston, Butterworth publishers, 496 - 512

[6] Alam IA and Sadiq M. (1993) metal concentration in Antarctic sediment samples collected during the TransAntarctica 1990 expedition. Marine pollution Bull. 26(1), 523 - 527.

[7] Abel PD. (1989) Water Pollution Biology. Ellis Horwood, Chichester, UK.

[8] Arah R0. (1985) Lead-free gasoline in Nigeria by the year 2000, Proceedings of Seminar on the Petroleum Industry and the Nigerian Environment. 339-346.

[9] Agbozu IE, Ekweozor IKE and Opuene K. (2007) Survey of heavy metals in the catfish Synodontis clarias. International Journal of Environmental Science and Technology, 4(1), 93-97

[10] Hart BT. (1982) Uptake of trace metals by sediments and suspended particulates: a review. Hydrobiologia, 91(2), 299-313.

[11] Black JJ. (1983) Epidermal hyperplasia and neoplasia in brown bull head (Ictalurus nebulosus) in response to repeated applicaton of a PAH containing extract of polluted river sediment. In M. cooke (eds) Plolynuclear aromatic and measurement. Battelle, press, Columbus Ohio, $99-111$.

[12] Smith JD, Hauser JY and Bagg J. (1985). Polycyclic aromatic hydrocarbons in sediments of the Great Barrier Reef region, Australia. Marine Pollution Bulletin, 16(3), 110-114.

[13] Iwegbue CMA, Egobueze FE and Opuene K. (2006) preliminary assessment of heavy metals levels of suits of an oil field in the Niger Delta Nigeria. International Journal of Environmental Science and Technology, 3(2), 167 172

\section{How to cite this article}

Alagoa KJ. (2019). An appraisal of heavy metals in water column and bottom substrate of Aba river, Abia state, Nigeria. GSC Biological and Pharmaceutical Sciences, 6(3), 45-50. 